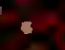




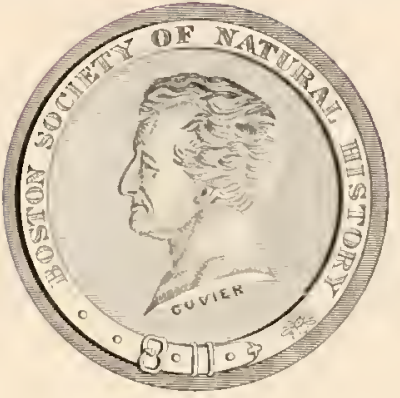

S.1.). Sumber ilibram

(iift of

WANUER HUTHEATID SCUTIDER

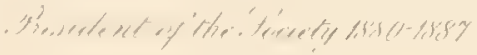

June 22, 1908 


\section{THE MARINE}

\section{BIOLOGICAL LABORATORY.}

BY

PROFESSOR E. G. CONKLIN.

Reprinted from ScIevoe, N. S., Vol. XII., No. 270, Pages 283-244, March 2, 1900. 


\section{TRUSTEES.}

PRESIDENT,

H. F. OSBORN.

MEMBERS ex officio.

C. O. Whitman, Director, University of Chicago, Chicago, Ill.

Utric Dahlgren, Assistant Director, Princeton University, Princeton, N. J.

E. G. Gardiner, Clerk of the Corporation, 13 I Mt. Vernon St., Boston, Mass.

TO SERVE TILL I $9 \circ 3$.

H. C. Bumpus, .........Brown University, Providence, R. I.

D. Blakely Hoar, Treasurer, 220 Devonshire St., Boston, Mass.

William A. Locy, ..... Northwestern University, Evanston, Ill.

JACQUeS Loeb,.........University of Chicago, Chicago, Ill.

J. M. Macfarlane,..University of Pennsylvania, Philadelphia, Pa.

F. P. Mall,..........Johns Hopkins University, Baltimore, Md.

TO SERVE TILL I 902.

E. G. Conklin,...... University of Pennsylvania, Philadelphia, Pa.

C. G. KIDder, .......27 IVilliams St., New York, N. Y.

M. M. Metcalf,......The Womans College, Baltimore, Md.

William Patten,..... Dartmouth College, Hanover, N. H.

D. P. Penhallow, ... McGill University, Montreal, Canada.

W. B. Scotr,..........Princeton University, Princeton, N. J.

TO SERVE TILL I 901 .

S. F. Clark,.........Williams College, Williamstown, Mass.

J. P. MCMURrich,....University of Michigan, Ann Arbor, Mich.

T. H. Morgan,.......Bryn Mawr College, Bryn Mawr, Pa.

L. L. Nunn, ...........Telluride, Col.

H. F. Osborn, President, American Museum of Natural History, New York, N. Y.

E. B. WrLson, .........Columbia University, New York, N. Y.

TO SERVE TILL I900.

W. K. Brooks, .......Johns Hopkins University, Baltimore, Md.

William LibBeY, ......Princeton University, Princeton, N. J.

W. T. SedGwick, ... . Massachusetts Institute of Technology, Boston, Mass.

William Trelense,... Missouri Botanical Gardens, St. Louis, Mo.

W. P. Wilson,........Philadelphia Museums, Philadelphia, Pa.

R. Ramsay Wright, University of Toronto, Toronto, Canada. 
[Reprinted from Sciexce, N. S., Vol, XI, No, 2ro, Puges 233-244, 1areh 2, 1900.]

\section{THE MARINE BIOIOGICAL, LABORATORT.}

The twelfth anuual session of the Marine Biological Isaboratory at Woods Holl, Mass., which was lield dluring the past summer, was lacking in none of the elements of interest and success which have made former sessions notable, while scveral new and valuable features were added last year for the first time. In addition to the regular courses of instruction in Zoology, Embryology and Botany, there was given last year, under the direetion of Professor Loeb, a conrse on Comparative Plysiology. Such a course can be given arlvantageously only at the seashore where living animals of all elasses may be had in abundanee. In the organization of this course the Woods Holl Laboratory has taken a unique and advanced position which cannot fail to yield valuable results not only to researeh but also to physiological instruction throughout the eountry. Another notable feature was the course of lectures and demonstrations in Comparative Psychology given by Dr. Thorndike. This course was followed with the keenest interest by a large number of persons at Woods Holl. The general lectures, a volune of whieh is published annually, were unusually numcrous and valuable. The faeilities for dredging in deep water and for making extensive collecting trips were never before so good, thanks to the eonrtcsies of the Fish Commission Station. The United States Fislı Commission steamer, Fishlanok and schooner Grampus, were stationed at Woods Holl and they, with the smaller vessels of the Commission and of the Marine Biological Laboratory, formed a fleet of vessels equipped for scientifie work such as has rarely assembled in one place before.

The attendance at the Laboratory was gratifyingly large; there were scventy-one investigators and seventy-eight students, representing sixty-nine different sehools, colleges and universities. When it is remembered that there were last year three other marine laboratories on our Atlantic eoast, offering their facilities freely, or for mueh less than the fee at the Marine Biological Laboratory, there is all the more reason for satisfaction at the large nnmber in attendance. In the eharneter and variety' of the research work done the past season was not exeelled by any preceding one, and in some respects it surpassed them all.

All these features show that the Marine Biological Laboratory is to-day, as much as at any time in its past history, the center of biological instrnction and investigation in this eountry. This can still be said in spite of the fitct that there are numerous other marinc and fresh water stations in this eountry, which are doing excellent work and are worthy of generous praise and support. However, no other Ameriean station has the national and even eosmopolitan eliaracter of the Woods Holl Laboratory; no other enjoys the coüpcration of so large a nnmber of educational and scientific institutions, no where clse is the whole field of biology so fully represented and no other 
Ameriean laboratory is so produetive in original work, nor has so large a number of investigators and students.

The Marine Biologieal Laboratory is a slining illustration of the faet that men and not buildings nor material equipment make an institution great. There is probably no other edueational $0 l^{\circ}$ seientific institution in the world whieh on so small a financial basis has aecomplished so great a work. This work is of such seientifie and edueational value and the Laboratory stands for so fine an ideal of seientific eoüperation that a brief aeeount of its history and work should not be wholly laeking in interest or suggestiveness.

The Laboratory can claim to be a lineal deseendant of the first marine labolatory in Ameriea, the sehool established by Louis Agassiz in 1573, on the island of Penikese, in Buzzards Bay. The Penikese Laboratory was abandoned in 1874 at the fortunate loeation of the laboratory on an isolated island, and above all by the death of the man whose genius had ereated it and who alone was able to seeure the scientific coöperation neeessary to its maintenance. After the elosure of the Penikese Laboratory an attempt was made to seeure the eoöperation of educational and seientifie institutions in establishing a marine laboratoly at Woods Holl, but the support was not fortheoming at that time and the projeet was abandoned.

In 1850 the WToman's Edueational Assoeiation of Boston, aeting in eoöperation with the Boston Soeiety of Natural History, opened a seaside laboratory at Amisquam, Mass., and this eontinued in operation for six years. In 1856 the supporters of that laboratory addressed a eireular letter to many leading biologists in this eountry asking their coöperation in the work of establishing the laboratory on a broader basis.

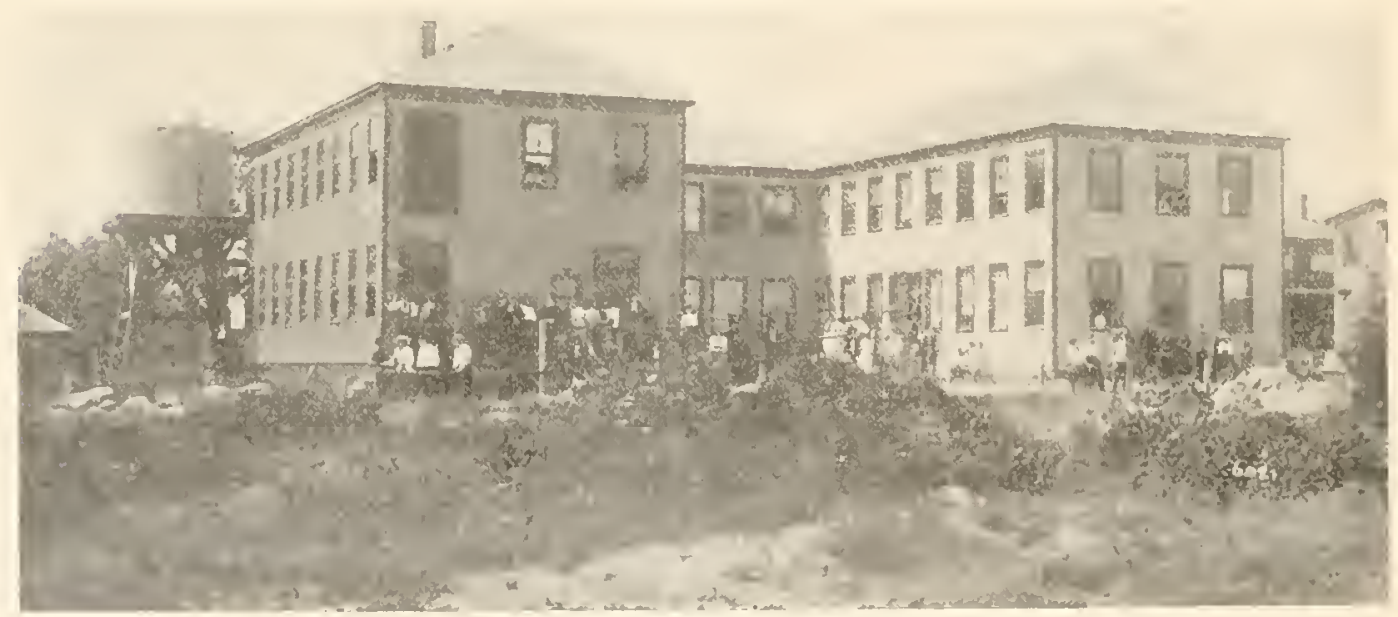

F1G. 1. Main Building, Marine Biological Laboratory.

close of its seeond session, after having reeeived in buildings, equipment and endowment, mole money than has been given to the Marine Piological Iaboratory during the twolve years of its history. 'This step' was made neeessary on aeeount of the nn-
In Mareh, 1887, a mecting of persons interested in the enterprise was held in Boston, and a committee was appointed " to perfeet plans for the organization of a permanent seaside laboratory, to eleet trustees and to dcrise ways and means for eolleeting the 
necessary funds.' In the spring of 1888 about ten thousand dollars had been secured, and aceordingly the Marine Biological Laboratory was incorporated and steps were taken to open it that season. After prolonged consideration the trustees decicled to locate the laboratory at Woods Holl, Mass, and the whole history of the institution has shown the wisdom of this decision.

The natural adrantages of Woods Holl deserve especial cmphasis because they have been fundamental to the snceess of the Laboratory. In a good location a biological laboratory may be highly successful with very little equipment, while in a poor location no amount of money can make up for this defeet.

In 1881 Professor Baild determined to locate the marine laboratory of the U. S. Fislı Commission at Woods Holl, after having in. vestigated, during the preceling ten years, almost every arailable point on the Atlantic coast. It is doubtful whether at any other single place on this coast so many valuable and important features can be found. The only other place seriously considered by Professor Baird was Newport, R. I., and this was finally rejected because of the relative impurity of the water of Narragansett Bay. On the other hand the waters of Buzzards Bay and Vineyard Sound ale of exceptional purity, there being no large fresh water streams in the vicinity nor eities discharging their filth into the waters. In the immediate vicinity of Woods Holl are numerous lıarbors and lagoons, with mnddy, sandy or rocky bottoms, while the const is so broken by bays, promontories, straits and islands as to afford the most varied habitats. In addition the tide currents which sweep in through the sound and 'hole' bring in multitudes of floating aninals and plants, many of which are tropical forms carried in fion the Gulf Stream, which is distant only about one liundred niles.
The proximity of the Gulf Stream to this portion of the New England coast gives a labolatory loeated at this point many of the advantages of a tropical station without any of the accompanying disadvantages. There are also many fresh water ponds and lakes in the vicinity which contain a rich fauna and flora. Add to these things the fact that Woods Holl is readily accessible by rail or boat, that the climate in summer is delightful, the bathing excellent, the mainland and islands charming, the sound with its continual procession of slips always varied and interesting, and you have in Wroods Holl not only an ideal place for a laboratory, but also an ideal place for summer residence.

Having determined to locate the Laboratory at Woods Holl, the 'Trustees bought a small piece of land near the Fish Commission Station and erected upon it a plain wooden building, $63 \times 28$ feet and two stories high. This was equipped with the most necessary apparatus and the Marine Biological Laboratory was first opener July $17,188 s$.

From the first it was determined that the Laboratory should not be under the control of any college, university or other institution, but that it slould be truly national in character and that it should invite the coöperation of all persons and institutions interested in the advancement of the science of Biology. Accordingly the Laboratory was organized on an independent foundation.

Its goverument was vested in a Corporation and a Board of Trusters. The Corporation, at first ten in number, now consists of several bundred persons, many of them present or former students and inrestigators at the Laboratory, who are interested in its welfare and have contributed to its support. The Corporation rlects annually six nembers of the Board of Trus- 
tees, passes upon all proposed changes in the Constitution and By-Iaws, hears an annual report from the Director and the Treasurer and makes such recommendations eoncerning the general policy of the Laboratory as it may lesire. The Board of Trustecs, at first seven in number, now consists of twenty-scven members, some of them business men of recognized ability, but most of them biologists representing prominent educational institutions in almost every part of the United States and Canada. The Board has direct clarge of the property and funds of the Laboratory, elects the Director and Assistant Director, and has general supervision of the scientific work.

From the first the institution las been under the directorship of Professor C. O. Whitman, and it is but simple justice to say that the remarkable snccess which has attended it is due in large mcasure to the high idcals and the untiring encrgy and sacrifice of Professor Whitman. For twelve years he has devoted himself to the Laboratory without compensation and with an enthusiasm which has served to inspire many others with his own ideals concerning the Laboratory and to enlist their learty coöp. eration.

In his address at the opening of the Laboratory and in subsequent publications, Professor Whitman took the position that therc was great need for a laboratory which should represent, (1) the whole of biology; (2) both teaching and research; (3) the widest possible coöperation of educational and seientific institutions. Such a laboratory should not be mercly a collecting station, nor a summer school, nor a scientific work shop, nor a congress of biologists, but all of thesc; an institution combining in itself the functions and features of the best biologieal institutes of the world, luaving the coöruation of the biologists of this country, and thus forming " a national center of instruction and research in every department of Biology." The history of the Laboratory las shown that this ambitions project is not only highly desirable, but that it is entirely feasiblc and has justified the claim of the Director that such an institution is the greatest need of American biology.

"The new laboratory at Woods Holl," said the director" in his first report, "is nothing nore and I trust nothing less than a first step toward the establishment of an idcal biological station, organized on a basis broad enough to represent all important features of the several types of laboratories litherto known in Europe and Amcrica. *** An undertaking of such magnitude cannot be a matter of local interest merely, and if it be pushed with energy and wislom, it cannot fail to receive the support of the universities, colleges and schools of the country." "There was little in the early conditions of the laboratory to justify such high hopes. It began with no assured cooperation, no constituency, a bare building, no library, no private rooms for investigators, only a row boat for collecting and with only two instructors, seven investigators and eight students.

Since that time the growth of the laboratory in material equipment has bcen enconraging, while its growth in numbers and in the scope and volunc of scientific work has been phenomcual. During the sccond season $\$ 1000$ was given to establish the Glendower Evans Library ; \$2500 was raised in Boston to establish two scholarships at the laboratory as a memorial to Lncretia Crocker, long a supervisor in the public schools of Boston. During the third season a lecture hall and hibrary room were constructed as an addition to the building and the 'Giflord IComestend,' together witl alout onc-half acre of land adjoining the Fish Commission was purchased, the house being converted into a dining lall; a steam launch was also 
seenred. In the fifth year an additional laboratory of the size of the original building was construeted. In the seventh year a new laboratory was built for botany and a large dining laall was ereeted, capable of aeeommodating two liundred people at one time. In the nintl year a building eontaining a large lecture hall and researeh laboratories was eonstrueted and a two. masted seliooncr was added to the fleet of eollecting boats.

Although this growth in material equipment has been rapid, the needs of the laboratory have grown still more rapidly. The bnildings are all of a temporary charaeter and can be used only in summer; at least one substantial, fire-proof building is needed whielı can be used the year aronnd; the library is inadequate to the needs of sueh aquaria and, although eorlial and mntually lelpful relations have always existed between the two stations, additional land, with shore privileges, ought to be sceured while it can be had; above all the Laboratory needs increascd endlowments both for special purposes, such as selıolarships, library, publieations, ete., and also for general maintenanee.

The growth in material equipment, though encouraging, is overshadowed in importance by the growth in the number of persons in attendance at the Laboratory. In 1885 there were nine investigator's and eight students representing thirteen different institutions of learning; in 1899 there were seventy one investigators and seventy-eight students representing sixtynine different institutions. In all during

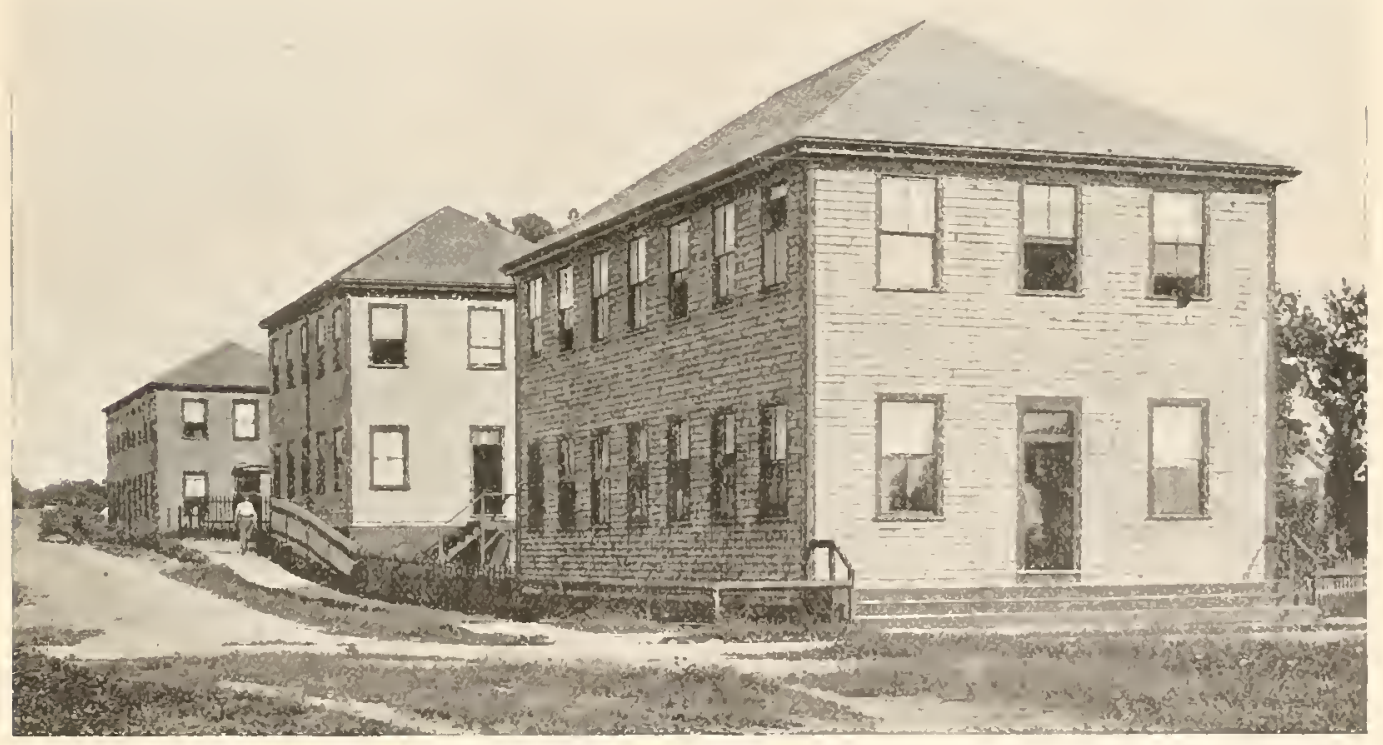

Fig. 2. Main Building, Botanical Laboratory, Leeture Ifall and Research Laboratory.

an institution; the facilities for eolleeting should be enlarged and inercased; the Laboratory is entirely dependent upon the Fish Commission Station for wharf privileges and for pumping sca water to its the twelve sessions there have been in attendance five lnmbred and ten investigators and seven hundred and forty-five students from nearly three lundred different educational and seientifie institutions, wlile 
among the occasional lecturers and visitors must be numbered ahnost all the better known biologists of this country and many from foreign lands.

As the ontgrowth of a summer sehool it might liave been expected that the laboratory would give instruetion in biological subjects, and at its very begimning its fonnders resolved that it should also give opportunity for original research. The combination of these two functions at the Laboratory has been a peculiarly fortmate one. It has been proved, not only here, but also in many universities and scientifie institutions, that resenrch and teaching are of mutual service. A eertain amount of teaching is stimulating to the investigator, while the atmosphere of researeh is indispensable to good teaching.

When the Laboratory was first estab. lished instruction was given in Koology only, since then conrses have been added and instructors, bnt also to the atmosphere of investigation which prevades the place and which is one of the most helpful features to the beginner, as well as to the advaneed worker. Instruction includes not only ordinary laboratory work" in the subject named, but also a great deal of observation and colleetion of living organisms in their natural liaunts. Collecting trips and exeursions form a regular part of the work, and a most important and enjoyable part. Investigators and cven visitors at the Laboratory eheerfully contribute to the work of instruction, and so it generally happens that the lectures are given by men who are specialists in the subjeets under eonsideration and who are able to teach with the enthusiasm, aecmaey and directness of 'those having authority.' When it is remembered that the persons in attendance at the laboratory are almost without exeeption teachers, the tremendous in-

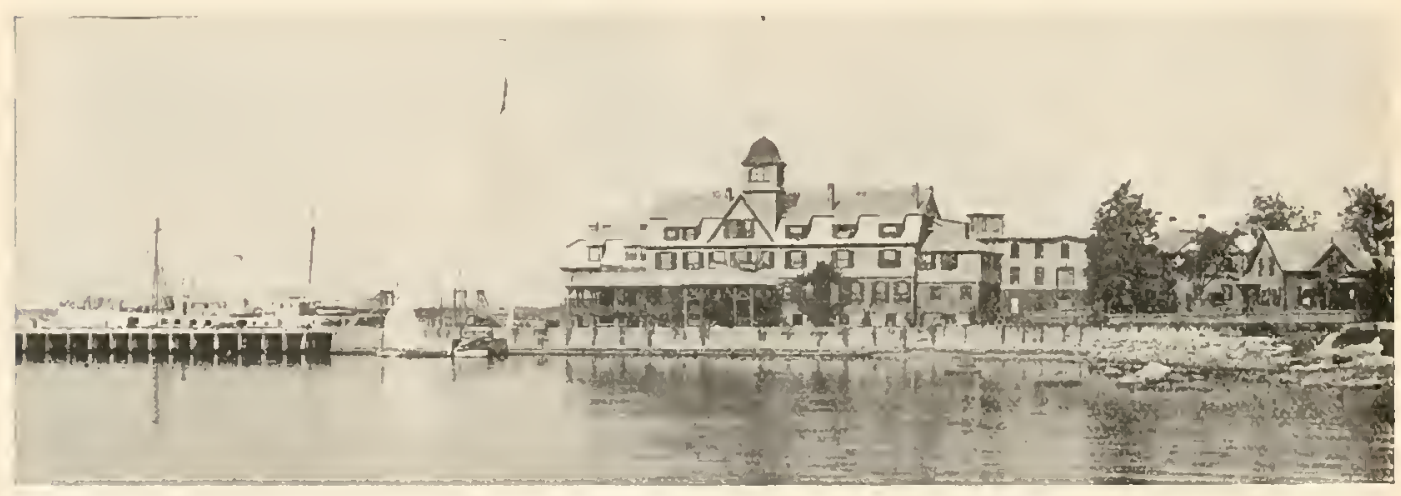

Fig. 3. Fish Commission Buildings, Wharf and Steamer; one of the Marine Biological Laboratory Buildings on the right.

in Botany, Embryology, Physiology and it is muderstood that Comparative I'sychology and Nature Study will form a part of the regulir program hereafter. In these cour'ses there is an earnestness and enthusiasm on the part of students and instructors which is highly stimulating. This is due not only to the exceptional chiracter of the students fluence of the Laboratory on the teaching of IBiology in the sehools, eolleges and nniversities of this country ean be surmised.

In 1891 a Supply Department was opence at the Laboratory for the purpose of furnishing to selnools and scientifie institntions various kinds of biological material to be found in the vicinity of Wools Holl. The 
collectors studicd the best methods of preserving material, the habitats and breeding seasons of various animals, etc., with the resnlt that the Supply Department has been not only a great financial assistance to the Iaboratory, but that it has still further contributed to the scientific purposes for with numerous colored plates, and some of them represent unique lines of research. For example, the study of 'cell-lineage,' as it has been called, had its origin at the Woods Holl Laboratory and has so far heen confined almost entirely to that institution. This work consists in tracing the cleavage

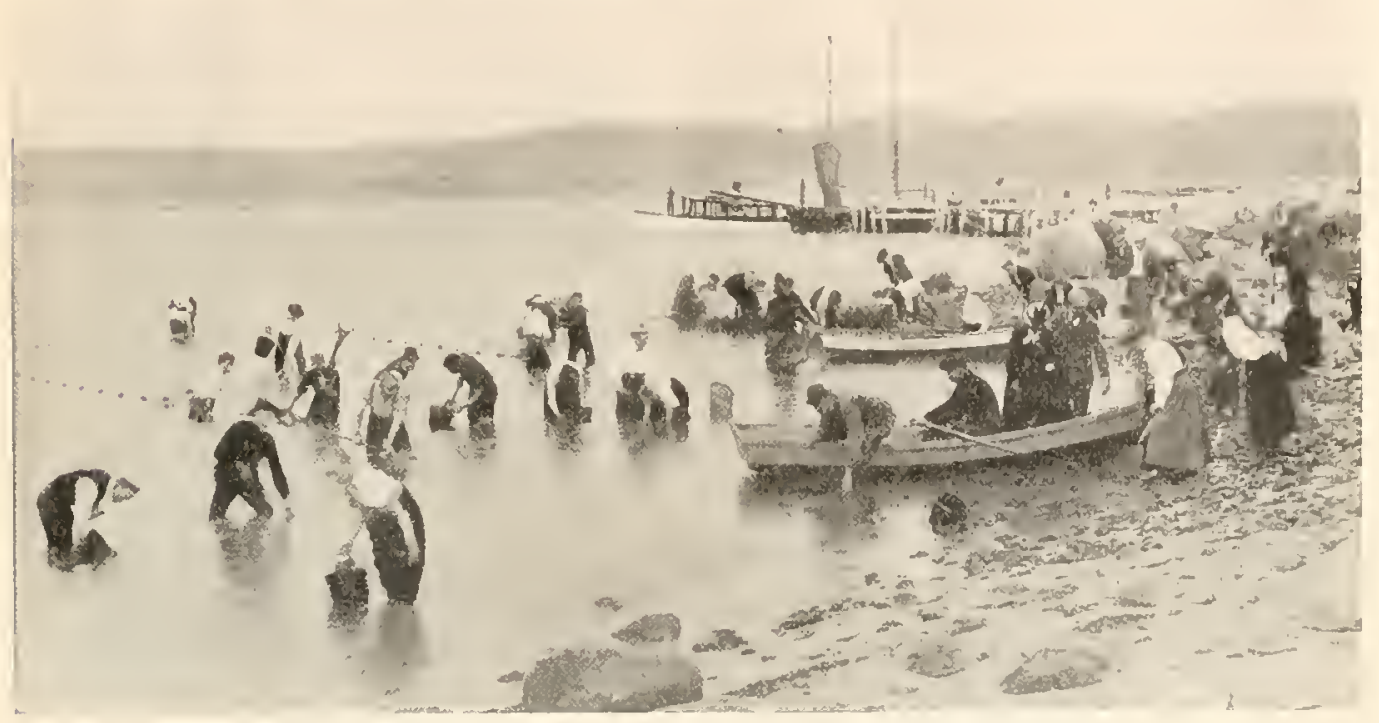

Fig. 4. A Collecting Trip; Launch and Sehooner in the Background.

whieh the Laboratory was established. At present a skilled eollector is cmployed the year around and material is gathered, not only from the vicinity of Woods Holl, but from far distant points.

But it is in the work of investigation that the Jaboratory has won greatest renown. The eminent scientific standing of the Director and his co-laborers has served to attract investigators from all parts of the land, until the Woods Holl Laboratory is to-day the Meeea of Ameriean biologists and is well and favorably known thoughout the workd. The list of original contributions which have proceeded from the Laboratory during the past twelve years numbers about three hundred; many of these are large monographs, illustrated cells, into which the developing eggs of all animals divide, through the whole development until they give rise to larval or adult organs, such as the brain, nerves, sense organs, glands, alimentary canal, etc. This is in all eases a difficult task, frequently taking years of the most painstaking labor, but its results lave been of funchunental and far reaching importance. Thanks to this work we now know the cell-lineage of about a seore of worms and mollusks. This work has shown that from their first appearance certain cleavage eells are destined to give rise to certain organs; it has shown that, in the groups mentioned, eleavage is as constant in its character as ar arbult features; that in animals so widely separated as flat-worms, annelids and mol- 
Iusks these early divisions of the egg are almost identicul and that many corresponding cleavage cells give rise to homologous organs. Incidentally such work has shown the close genetic relationship of the groups named; it has also set a new pace in cmbryology. Now that we know the cxact cell origin of these layers and organs, it will never again be possible in describing the development of these animals to refer the origin of certain organs to 'germ layers' merely, nor to refer the origin of these layers to eertain general regions of the embryo. The importance of this line of work, not only in the study of the groups named, but also to the science of embryology as a whole, is fully recognized both in this country and abroad, and the credit for this service belongs in large part to the Woods Moll Laboratory.

Other work of the greatest importance has been done in the line of what has been called 'physiological morphology.' It would exceed the limits of this article to give even a brief description of papers of this class which have issued from the Laboratory. A few of the more striking lines of work, however, must be mentioned. Much attention has been given to cxperiments on the regeneration of lost parts in various animals. In hydroids, sea-ancmones and worms these parts are sometimes reproduced in a normal manner, while under different conditions a head may be caused to develop where a tail belongs or vice versa. Another line of work has becn the grafting togetler of different parts of aninals. One member of the Labaratory succeeded in grafting together in almost every possible manner the pupa of different moths and butterflies. Some of these afterwards went through the metamorphosis and came out as 'Siamese twins,' 'tandroms' with four wings, etc. Another line of work, cven more important, is found in 'experinental embryology.' In one fa- mous experiment performed at the Labora. tory, the eggs of the sea-urchin were artificially fragmented before they began their development, and in this way twins, triplets, or still more numerous larve might be produced from a single egg. If the fragments of the egg were entirely separate, the larva which developed were separate and perfect, if they were united, the larve were united forming all kinds of double or multiple monsters. Other experiments have shown that certain salt solutions will cause unfertilized cggs to develop for a short time in an irregular way, and only last snmmer Professor Locb discovered that he could cause the unfertilized eggs of the seaurchin to develop into normal larva, in short, could produee artificial parthenogenesis in a phylum in which it has never before been known, by treating them with certain salt solutions; this is certainly one of the most remarkable biological discoveries of recent ycars. The limes of work outlined above, together with many which could not here be mentioned, and which have been actively prosecuted at the IToods Holl Iaboratory, have been substantial eontributions toward the solution of some of the most fumdaniental problems of biology.

Euch year a course of gencral lectures on various phases of biological work is given by different members of the Lahoratory and by distinguished visitors. These lectures are usually brief a ecounts of important investigations, presented in a popular form. A volume of these lectures is published annually and the contents of the volumes form a brief index to the multifarious activities of the Laboratory in research. These volumes are not only important contributions to knowledge, but still more, they are brief and popular presentations of what are often abstruse and diflicult subjects, and as such they appeal strongly to inrestigators, teachers and general readers who 
secured. In the fifth year an additional laboratory of the size of the original building was constructed. In the seventh year a new laboratory was built for botany and a large diuing hall was crected, capable of accommodating two hundred people at one time. In the ninth year a building containing a large lecture hall and rescarch laboratories was constructed and a twomasted schooner was added to the fleet of collecting boats.

Although this growth in material equipment has been rapicl, the needs of the laboratory have grown still more rapidly. 'The buildings are all of a temporary character and can he used only in summer; at least one substantial, fire-proof building is needed which can be used the year around; the library is inadequate to the needs of such aquaria and, although cordial and mutually helpful relations have always existed between the two stations, additional land, with slore privileges, onght to be sceured while it ean be had; above all the Laboratory needs increased endowments both for special purproses, such ais scholarships, library, publications, etc., and also for gencral maintenance.

The growth in material equipment, thougl encouraging, is overshadowed in importance by the growth in the number of persons in attendance at the Iaboratory. In $185 s$ there werc nine investigators and eight students representing thirteen different institutions of learning; in 1899 there were seventy one investigators and seventy-eight students representing sixtynine different institutions. In all duling

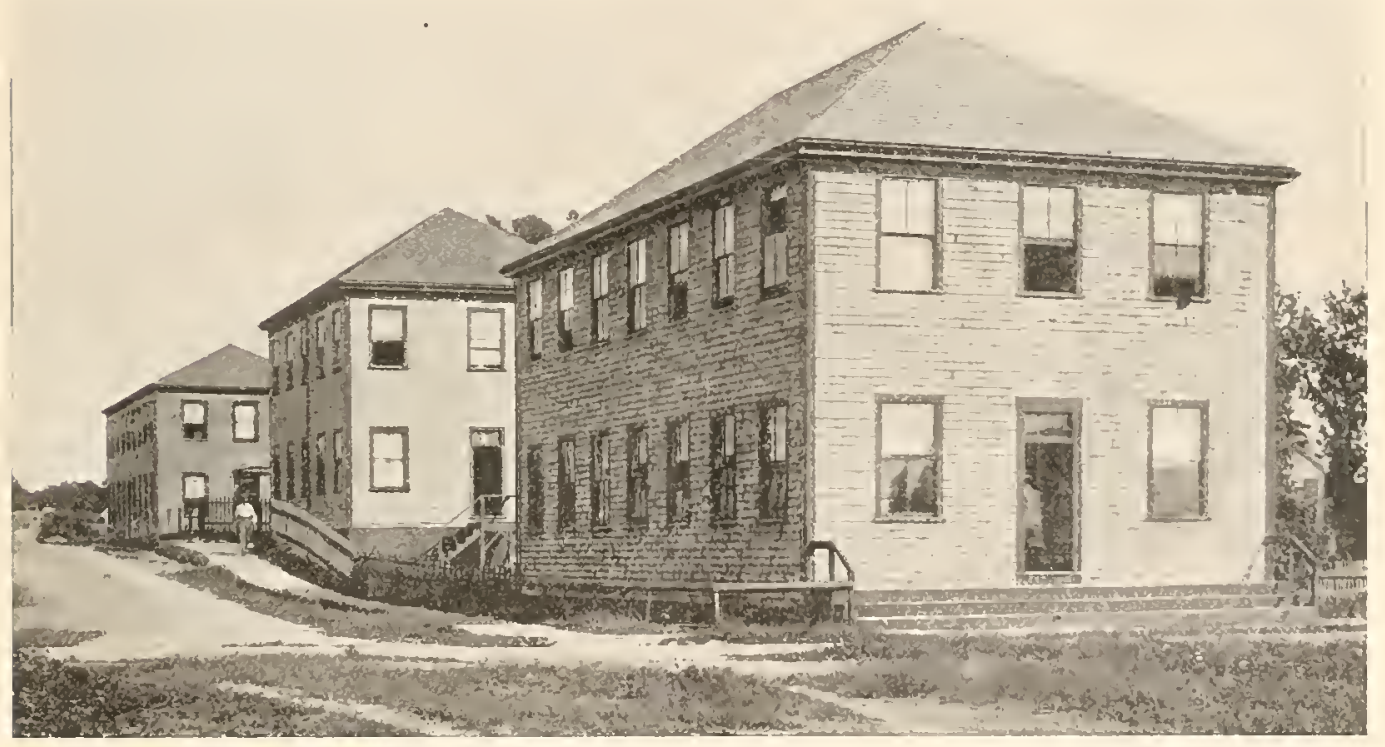

Fig. 2. Main Building, Botanical Lahoratory, Lecture Hall and Research Labolittory.

an institution; the facilities for collecting should be enlarged and increased; the Isaboratory is cntirely dependent upon the Fish Commission Station for wharf privileges and for pumping sea water to its the twelve sessions there have been in attendance five lrundred and ten investigators and seven lundred and forty-five studints from nearly three lundred different educational and scientifie institutions, while 
lusks these early divisions of the egg are almost identieal and that many corresponding eleavage eells give rise to homologous organs. Ineidentally such work has shown the elose genetie relationship of the groups named ; it has also set a new paee in embryology. Now that we know the exaet eell origin of these layers and organs, it will never again be possible in deseribing the development of these animals to refer the origin of eertain organs to 'germ layers' merely, nor to refer the origin of these layers to eertain general regions of the embryo. The importanec of this line of work, not only in the study of the groups named, but also to the seienee of embryology as a whole, is fully reeognized both in this country and abroad, and the eredit for this service belongs in large part to the Wools Holl Laboratory.

Other work of the greatest importanee has been done in the line of what has been ealled 'physiologieal morphology.' It would exeeed the limits of this artiele to give even a brief description of papers of this class which have issued from the Laboratory. A few of the more striking lines of work, however, must be mentioned. Iucl attention lias been given to experiments on the regeneration of lost parts in various animals. In hydroids, sea-anemones and worms these parts are sometimes reproduced in a normal manner, while under different eonditions a lead may be caused to develop where a tail belongs or vice versa. Another line of work has been the grafting together of different parts of animals. One membre of the Laboratory sueceeded in grafting together in almost every possible manner the pupa of different motlis and butterflies. Some of these afterwards went through the metamorphosis and eame out as 'Siamese twins,' 'tandens' with four wings, ete. Another line of work, even more important, is found in 'cxperimental embryology.' In one fa- mons experiment performed at the Laboratory, the eggs of the sea-urehin wcre artifieially fragmented before they began their development, and in this way twins, triplets, or still more numerons larva might be produced from a single egg. If the fragments of the egg were entirely separate, the larve whieh developed were separate and perfect, if they were united, the larve were united forming all kinds of double or multiple monsters. Other experiments have shown that eertain salt solutions will eause unfertilized eggs to develop for a short time in an irregular way, and only last summer Professor Loeb discovered that he eould eanse the unfertilized eggs of the seaurehin to develop into normal larve, in short, eould produee artificial parthenogenesis in a phylum in which it has never before been known, by treating them with certain salt solutions; this is eertainly one of the most remarkable biological diseoveries of recent years. The limes of work outlined above, together with many which eould not here be mentioned, and which have been aetively proscented at the Woods Holl Laboratory, have been substantial eontribntions toward the solution of some of the most fundamental problems of biology.

Each year a eourse of general leetures on various phases of biologieal work is given ly different members of the Laboratory and by distinguished visitors. These letrures are usually brief aecounts of important inrestigations, presented in a popular form. A volnme of these leetures is published amnually and the contents of the volumes form a brief index to the multifarious activities of the Laboratory in rescareh. 'These volumes are not only important contributions to knowledge, but still more, they are bricf and popular presentations of what are often abstruse and diffieult subjects, and as such they appeal strongly to investigators, teaehers and general readers who 
have not the time to go more fully into these subjeets. As showing the opinion of the outside world with regard to these lee. tures, the following is quoted from Nutural Science, Deeember, 1899: "Every biologist who is still young enongh to be enthusiastie, looks with eagerness about this time of year for the arrival of the volume of "Biologieal Leetures' from the Marine Biological Laboratory, Woods Holl, Mass, *** * One cannot help feeling that the intelleetual atmosphere of Woods Holl must be braeing, the leetures are so vigorous. The eharm of these leetures may be partly due to the eireumstanees of their delivery, but it is doubtless mainly due to the fuct that eaeh is an expression of personal work and personal interest. One eannot lut be grateful to the Laboratory at Woods Holl, whieh has been the stimulus of the fine series to whieh this volume is added. Floreut Wools Holl." In addition to the volume of lectures there is also published under the auspices of the Laboratory the Hiologicul Bulletin, as well as the Annual Reports and Anuoumeements.

The serviee which the Laboratory las rendered to biologieal instruetion in our sehools and eolleges and to advaneed work in biology in general is inealeulable; it is the biological clearing louse of this country, where the specialist who has been unable to keep up with the general advanec of his seienee may learn from others what has been transpiring in fields ontside his own, where teachers may exehange icleas as to the best methorls of instruetion, where distinguisled men in various fields come to know each other in the most intimate and helpful way, and where all may get broader and truer ideas of the great problems of biology. The Labolatory is also a plaee to whieh schools, colleges and universities are coming to look for good men. This feature has never before been emphasized and it reeeives no direet attention at $1 V^{\prime}$ oods Hall, but if the indirect influence of the Laboratory in diseovering good men and plaeing them in good positions were known, it would be seen that this feature is no small part of the service whiel the Marine Biologieal Laboratory renders to Ameriean biology.

The eonfidenec of the Direetor that the Laboratory would not fail to reeeive the support of the schools, eolleges and universities of the eountry has been fully justified. During the past twelve years representatives from about three hundred schools and higher institutions of learning have been in attendance at the Lal oratory, while twontyseven eolleges and universities and three soeieties have bcen regular subscribers to Rooms and Tables. The Laboratory has now grown to such proportions that it eannot expect to drawany large part of its finaneial support from educational institutions, already overburlened. It is itself an clucational and seientific institution of highest rank, and howevel measured, deserves to stand alongside the best seientific seliools and laboratories of the world. "It is aeknowledged that only one similar institution in the world (Naples) is more produetive in original researeh, and no other offers even approximately equal arlvantages for instruction." Sueh an institution deserves and expeets independent support.

The present finaneial eondition of the Laboratory is shown by the following figures:

\section{Total Asqets.}

Estimated value of real estate, buildingrs and equipment at Woods Holl. .............. \$35,000.

Invested Funds.

General Endowment.............. 4,553 . Lncretia Crocker fund............. . $2,500$. Library Fund................... 866. Interest on hand..............

Total I,iabilities.

$\$ 43,149$.

Mortgage on Wrouls 11 oll property .... . . . \$2,900.

Unsecured loant . . . . . . . . . . . 5, 276.

\$8, 176 .

Assets less liabilities.............. \$31,937. 
The total earnings of the lahoratory as compared witl its expenses are given herewitl. ('Earnings' include all sources of income save donations only ; 'expenses' include all disbursements save those for land, buildings and permanent equipment.)

Total Donations................. \$37, 730 .

Earnings ................... $\$ 17,919$.

Expenses ................... 50,759 .

It appears from this statement that the income of the Laboratory, like that of scicntitic and elucational institutions in general, is scarcely sufficient to meet the running expenses, and that it must look to the donations of interested friends for assistance in meeting a small anmual deficit and for all permanent equipment and enlargement. This is a fact which requires no apology; the Laboratory is not a com. unercial enterprise but a charitable institution, in the same sense that colleges and universities are such. It is not the purpose of the Labolatory to make money, but rather to contribute as much as possible to the advancement of seience, and in this respect it has fulfilled the highest hopes of all its friends. There is every reason to be proud of the fact that it has accomplished so great a work on so small a financial basis, and that it is at present so nearly self-supporting as it is.

The Trustees at their meeting in New Haven, December " 9 th last, resolved that for the best interests of the Laboratory the out-standing debt of $\$ \$, 176$, should be paid off at once and that a small cash balance should be left in the hands of the Treasurer. They, thereforc, appeal to the friends of the Laboratory to contribute $\$ 10,000$ to this end. Subscriptions may be sent to the 'Treasurer, D, Blakely Hoar, 220 Devonshire Street, Boston, or to any member of the Board of Trustces.

The time has come also when to give the Labolatory the stable and permanent character which it deserves it should be liberally cndowed. Where conld a better investment be made than in a scicntific and educational institution with such a history behind it and such excellent prospects before? The Laboratory and the ideals for which it stands must not be allowed to suffer for lack of support; it must not remain standing where it is, for although its suecess has bcen remarkable, it is only the beginning of what it should and could do, if properly supported. The aim of those who ale interested in its welfare is to ereate a permanent station with adequate endowment and equipment which shall be in the future yet more than in the past 'a national center of rescarch in every department of Biology.'

For this end its friends labor and wait, hoping that the time is not far distant when generous friends of seicnee and education will see its nceds and its opportunities and will not be slow in their response.

E. G. Conklis.

UNIVERSTY OF PENASTLYANIA. 




DIGEST OF THE

\section{LIBRARY REGULATIONS.}

No book shall be taken from the Library withont the record of the Librarian.

To person sliall be allowed to retain more than five volnmes at any one time, nuless by special rote of the Council.

Books may be kept out one calendar month; no longer without renewal, and renewal nay not be granted more thau twice.

A fine of five cents per day incurred for every volume not returned within the time specified by the rules.

The Librarian nuy demand the return of a book after the expiration of ten days from tbe date of horlowing.

Certain books, so designated, cannot be taken from the Library without special permission.

All books must be returned at least two weeks previous to the Annual Meeting.

Persons are responsible for all injury or loss of bnoks charged to their name. 
